\title{
Blood Pressure and Control Factor in Hypertensives Monitored at the Referral Hopsital in Boma. Democratic Repubic of the Congo
}

\author{
Blaise Makoso Nimi ${ }^{1,2}$, Bernadette Nzuzi Phaka ${ }^{3}$, Rosette Pfuti Nlandu ${ }^{2,4}$ and Fabrice Nlandu Thamba ${ }^{2,4}$ \\ ${ }^{1}$ Division of Cardiology, University of Kinshasa Hospital, Kinshasa School of Medicine, University of Kinshasa, Kinshasa, The \\ Democratic Republic of the Congo \\ ${ }^{2}$ University Kasa Vubu School of Medicine, Boma, DRCongo \\ ${ }^{3}$ Higher Institute of Medical Technology (ISTM), Tshela \\ ${ }^{4}$ BomaHospital,DRCongo
}

Abstract:-

> Background and Aim:

Uncontrolled hypertension remains a significant problem in daily clinical practice worldwide.

Few data are available on blood pressure control in hospitals. The aim of this study was the frequency of uncontrolled hypertension and associated risk factors in hypertensive patients followed at the general referral hospital of Boma in the province of Kongo Central in the Democratic Republic of Congo

\section{$>$ Methods:}

From January 1 to May 31, 2019; we conducted a cross-sectional and descriptive study at the Boma reference hospital located in the southeast and $440 \mathrm{Km}$ from Kinshasa, the capital of DR Congo.

Included was any hypertensive patient aver 18 years and informed consent. Information on demographic parameters, behavioral lifestyles, anthropometric and biological (blood sugar, creatinine, urine strip and lipid profile ) and blood pressure (BP) measurements was obtained. Hypertension was defined as an average of two $B P \geq 140 / 90 \mathrm{mmHg}$. Independent factors associated with control hypertension were identified using logistic regression analysis. $\quad P<0.05$ defined the level of statistical significance.

\section{$>$ Results:}

The prevalence of uncontrolled hypertension was $62 \% \mathrm{BP}$ control was observed in $150(38.0 \%)$ of 395 treated hypertensive participants mainly in men than women (68.3 vs $53.3 \%$; $p=0.001)$. Age $<60$ years ( $p=0.005)$, no smoking $(\mathrm{p}=0.047)$, no Central obesity $(p=0.008)$, CKD ( stade 1 vs 2$)(p=0.065)$, and no hypercholesterolemia $(p=0.014)$ emerged as associated with control hypertension.

\section{Conclusion}

Uncontrolled hypertension was common in our hospitals.Therapeutic lifestyle changes and pharmacological treatment are necessary for hypertensive participants.
Keywords:- Hypertension, Control, Risk, Factors, Hospital, Boma.

\section{INTRODUTION}

Since independence, the prevalence of hypertension (HTN) has steadily increased in Sub- Saharan Africa (SSA) from $<5 \%$ to $40 \%$ to day and is a major health problem [1].

Several reasons are cited to justify this increase among other, rapid and uncontrolled urbanization, physical inactivity, obesity and above all the abandonment of the traditional way of life [2].

In SSA, HTN is the primary modifiable and preventable risk factor responsible for stroke, heart failure and kidney disease $[3,4]$.

Adequate control of HTN is critical to prevent cardiovascular events. Several factors of non-control of HTN are reported in the literature among which advancement in age, alcoholism, physical inactivity, therapeutic inertia, drugs of dubious quality, poverty and without forgetting chronic renal disease [5-8].

Although there are some data showing differences in the prevalence, awareness and degree of control of HTN in low and middle income countries, studies agree that there is an effort to be made to wait the level acceptable[9 -11].

In the Democratic Republic of the Congo (DRC), then nationwide prevalence of hypertension, in studies conducted in some urban and rural areas have reported a prevalence of hypertension ranging from $30 \%$ to $40 \%$ [9,12-16].

In hospitals, the prevalence of uncontrolled HTN is very high, indeed, Kika et al in Kinshasa found that $77.5 \%$ of hypertensive patients have uncontrolled HTN [17], Katchunga et al, in Southern Kivu (DRC), foundthat $86.4 \%$ of hypertensive patients were uncontrolled [15].

The good HTN management can save patients from life- threatening complications. To achieve this, adequate treatment and taking care of other cardiovascular risk factors. To our knowledge, very few studies have been 
carried out the hospital in order to list the factors of no control of HTN, reason for being in this study.

\section{METHOD}

From January 1 to May 31,2019; we conducted a cross-sectional and descriptive study at the Boma reference hospital located in the southeast and $440 \mathrm{Km}$ from Kinshasa, the capital of DR Congo.

Included was any hypertensive patient aver 18 years of age on antihypertensive medication in the past two years. The parameters of interest were age, sex, the notion of taking tobacco and alcohol, physical examination including blood pressure, height, weight, the waist and the biological parameter : blood sugar, creatinine, urine strip and lipid profile.

The anthropometric measurements (such as body weight, waist circumference, height) blood pressure, and pulse rate were collected by well-trained Medical students. Blood pressure was measured using digital blood pressure measurement devices (OMRON MIT5 Connect, Kyoto, Japan. The averageof the two measurements were used in the analysis.

Height was measured, while the participants were in an upright position without shoes, by using a flexible tape meter (Hemostyl, Sulzbach, Germany). Body weight was also measured with individuals wearing light clothing or standing without shoes using adigital weighing scale (Deluxe GBS-721; Seca Deutschland, Hamburg, Germany). Body mass index (BMI) was computed as weight in kilograms divided by height in meters squared $\left(\mathrm{Kg} / \mathrm{m}^{2}\right)$.

A flexible tape meter was used to measure the waist at the level directly above the iliac crest.

\section{- Operational definitions}

BP control BP $<140 \mathrm{mmHg}$ while on treatment among those on treatment; isolated systolic, isolated and systolicdiastolic uncontrolled BP in treated patients were defined as $\mathrm{SBP} \geq 140 \mathrm{mmHg}$ and $\mathrm{DBP}<90 \mathrm{mmHg}, \mathrm{SBP}<140$ $\mathrm{mmHg}$ and $\mathrm{DBP} \geq 90 \mathrm{mmHg}$ and $\mathrm{SBP} \geq 140 \mathrm{mmHg}$ and $\mathrm{DBP} \geq 90 \mathrm{mmHg}$, respectively [18]. Diabetes was defined as fasting blood glucose, $110 \mathrm{mg} / \mathrm{dl}$ or history of antidiabetic treatment [19].Body Mass Index (BMI): computed from the height and weight of the respondent - weight divided by height squared $\left(\mathrm{Kg} / \mathrm{m}^{2}\right)$. The BMI was further classified into four categories; underweight (BMI $<18.5 \mathrm{Kg} / \mathrm{m}^{2}$ ), normal (BMI 18.5-24.99 Kg/m²), overweight (BMI 25 $\left.29.99 \mathrm{Kg} / \mathrm{m}^{2}\right)$ and obese $\left(\mathrm{BMI} \geq 30 \mathrm{Kg} / \mathrm{m}^{2}\right.$ [20].

Waist circumference (WC) was used as surrogate for abdominal obesity, defined as a WC value $>94 \mathrm{~cm}$ in men and $>80 \mathrm{~cm}$ in women [21].

Smoking was defined as current use of smoked or smokeless tobacco [22].
Talking alcohol was defined as consumption of more than 1 standard drink (which is the amount of alcohol you find in a small beer, one glass of wine, or one tot of spirits per day for females and more than 2 standard drinks for males [23].

While on their usual diet, a venous blood sample was taken from an antecubital vein for the determination of levels of cholesterol and its sub-fractions, and triglycerides using enzymatic methods (Biomérieux France). Low-density lipoprotein cholesterol (LDL-C) was calculated using the Friedewald formula.[24].For estimated glomerular filtration rate (eGFR) determinations, the abbreviated equation from the MDRD study was used. [25].

\section{$>$ Data analyses}

Data were analyzed using Statistical Package for the Social Sciences (SPSS) version 21 for Windows (SPSS Inc., Chicago, IL, United States). Data were expressed as mean values \pm standard deviations (SD) for continuous variables. Frequencies (n) and percentages (\%) were reported for categorical variables. Counts (frequency $=n$ ) and percentages (\%) were reported for categorical variables. Percentages were compared using the chi-square test. The logistic regression model analysis adjusted . A pvalue of $<0.05$.

\section{Ethical considerations}

The study protocol was reviewed and approved by the institutional review board of the Kinshasa School of Public Health. All study participants provided written informed consent.

\section{RESULTS}

\section{Table 1 General characteristics}

Of the 395 participants, 230 (58.2\%) were males while $165(41.8 \%)$ were females. Their mean age was $51,3 \pm 12,1$ years with $33.7 \%, 23.0 \%, 13.4 \%, 9.6 \%$ and 20.3 $\%$ participants aged participants aged respectively $<30$ years, 30-39 years, 40-49 years, 50-59 years and $\geq 60$ years . The proportion of unemployed, married, single, secondary education level and low SES participants was $43.0 \%$, $46.6 \%, 59.0 \%$, and $63.5 \%$, respectively.

Average levels of SBP, DBP, MAP, WC BMI,blood glucose, Total Cholesterol, Triglyceride, 24 hour protein,Blood Creatinine $\mathrm{mg} / \mathrm{dl}$, DFGe-MDRD were $125,9 \pm 18, \mathrm{mmHg}, 81,1 \pm 10,7 \mathrm{mmHg}, 96,0 \pm 12,3 \mathrm{mmHg}$, $25,1 \pm 4,9 \mathrm{Kg} / \mathrm{m}^{2}, 88,9 \pm 12,3 \mathrm{~cm}$ and $184,4 \pm 76,2 \mathrm{mg} / \mathrm{dl}$, $174,9 \pm 48,3 \mathrm{mg} / \mathrm{L}, 100,8 \pm 50,7 \mathrm{mg} / \mathrm{dl}, 154,9 \pm 48,8 \mathrm{~g} / \mathrm{dl}$, $1,08 \pm 0,34 \mathrm{mg} / \mathrm{dl}$ and $94,8 \pm 40,2 \mathrm{ml} / 1,72 \mathrm{~m}^{2}$ respectively.

\section{Table 2 summarizes}

By including the risk factors between patients with controlled and uncontrolled HTN, the study reports that the uncontrolled had significantly elevated, notion of tobacco use (93.5 vs $84.0 \%$ ), Abdominal obesity (53.5 vs $32.5 \%$ ), $24 \mathrm{~h}$ Prot $(320.6 \pm 75.7$ vs $53.4 \pm 11.9 \mathrm{mg} / \mathrm{dl}$, DFGeMDRD $(102.8 \pm 45.7$ vs $81.6 \pm 24.3 \mathrm{ml} / 1.72 \mathrm{~m} 2$ of body 
surface area were cardiovascular risk factors most frequently reported by the participants.

This study identified that out of all hypertensive therapy, the antihypertensive regimen was based on 1 and 2 antihypertensive drugs in $245(62.0 \%)$ and $150(38.0 \%)$ treated hypertensive participants, respectively; no participant was receiving $\geq 3$ antihypertensive drugs.

In those receiving one antihypertensive drug, calcium channel blockers (69.4\%) was the drug class most frequently reported by participants whereas the combination of calcium channel blockers (CCB) and angiotensin converting enzyme inhibitors (ACEIs) (21.6\%) was most frequently mentioned by those receiving two drugs.

BP control was observed in $150(38.0 \%)$ of 395 treated hypertensive participants mainly in men than women (68.3 vs $53.3 \%$; $\mathrm{p}=0.001)$.

Systolic-diastolic uncontrolled hypertension $(52.7 \%)$ was the type most frequently encountered among those with no BP control

In univariable logistic regression analysis, age $\leq 60$ years, no smoking, no obesity, chronic kidney disease stage 1 or 2 and the absence of hypercholesterolemia were associated with controlled BP.

In multivariate analysis (Table 6), the strength of the associations observed in univariate analysis persisted only for older age <60 years [aOR $3.43(1,42-4,84) ; \mathrm{p}=0.005]$, no smoking [aOR 4.91(1.32-11.32); $\mathrm{p}=0.047$ ], no Central obesity (aOR 3.30(1.49-6.49); $\mathrm{p}=0.008$ ], CKD ( stade 1 vs 2 ) [aOR 1.017(0.99-1.04); $\mathrm{p}=0.065$ ], and no hypercholesterolemia [aOR 2.20(1.76-6.35); $\mathrm{p}=0.014$ ],

\section{DISCUSSION}

This study first discovers that $4 / 5$ of hypertensive is under age of $60,65.8 \%$ drink alcohol, $89.9 \%$ smoke and $45.6 \%$ have central obesity. Second, the men was more received at the hospital, the blood glucose, the total cholesterol and the glomerular filtration rate were higher in the men than the women. Third, age $<60$ years, no smoking, no central obesity and no hypercholesterolemia emerged as a factor in controlling hypertension. By comparing controlled hypertensive to uncontrolled patients, the study discovered that the uncontrolled patients had a statistically significant notion of greater tobacco use, central obesity and proteinuria. socio-demographic factors such as age and level of education, marital status and socioeconomic level were significantly associated with uncontrolled hypertension in this study, which is reported in several other studies

In this study, $62.0 \%$ of patients had uncontrolled hypertension. This observation agrees with previous reports highlighting the fact that in most countries, less than $20 \%$ of patients achieve BP goals and therapy with a single antihypertensive agent fails to achieve BP goals in up to $80 \%$ of patients [1]

The prevalence of uncontrolled hypertension observed in the present study was similar than that reported by Dennison et al. (64\%)[26], Rayner et al. (60.2\%)[27].and by Abiodun et al $.62 .3 \%$, $(67 \%)$ [28]. It lower than that reported by Mutua et al (66.4\%) [29], by Ayodele et al. (68.6\%) [30] Sani et al. (67\%)[31], Onwemu et al. (70.4\%) [32] and Kika et all in DRC $(77.5 \%)$.It was higher than that reported by Sangsuwan et al $(53.4 \%)$ [33], Olowe et al $(51 \%)$ [34], Jafar et al $(58.0 \%)$ [35], Sarfo et al (57.7\%) [36] and Ojo et al ( 53.6\%) [37]

The differences in these studies can be justified by the media, the different sample sizes, the references retained as control (140/90 and BP.130 / $80 \mathrm{mmHg}$ ), and finally the co-morbidity in the presence (CKD and DM) and without forgetting the quality of the drugs which differs from country to country

The majority of treated participants were receiving monotherapy with mainly calcium channel blockers.

So current recommendations require debiting treatment with low-dose, fixed-dose dual therapy in order to avoid complications and obtain good adherence to treatment [18], is conceptually rationale, the use of monotherapy in the present study where hypertension is associated with high to very high 10 years global cardiovascular risk is not rationale and may translate therapeutic inertia from caregivers [38].

Age $<60$ years, no smoking, no central obesity and no hypercholesterolemia emerged as a factor in controlling hypertension.

Uncontrolled SBP is more frequent and its frequency increases with advancing age, especially after 60 years.

Older age has been reported to be one of the most powerful cardiovascular risk factors through oxidative stress-induced endothelial dysfunction [39] and subsequent vascular remodeling as well as the coexistence of multiple cardiovascular risk factors via insulin resistance [40].

Smoking [41] and overweight/obesity are well-known traditional risk factors sharing insulin resistance, sympathetic nervous (SNS) and renin angiotensin aldosterone (RAAS) systems, oxidative stress and subsequent inflammation and endothelial dysfunction as a common pathogenic pathway for cardiac and vascular damage [42].

The present study confirms that the absence of hypercholesterolemia plays an important role in the control of hypo-dependent hypertension in black Africans [43]. Therefore, this could be explained by the absence of fat in the vessels causing good compliance [44]. 


\section{CONCLUSION}

Uncontrolled hypertension was frequent in the present series of cases, the causes of which can be, inter alia, therapeutic inertia or an increase in effective management in order to avoid complications.

\section{ACKNOWLEDGMENT}

The authors wish to express their deep gratitude to the authorities and academic staff of Kasa Vubu University in Boma for their invaluable help. We are deeply redevelop able to all students for their commitment to the reuse of the site of this survey.

\section{REFERENCES}

[1]. Houehanou C, Amidou S, Preux M, et al. High blood pressure in sub-Saharan Africa. Journal of Vascular Medicine 2018 March; 43 (2): 87.

[2]. Mills K,Bundy J,Kelly T,Reed J,Kearney P,Reynolds $\mathrm{K}$, et al .Global disparities of hypertension prevalence and control: a systematic analysis of population based studies from 90 countries. Circulation .2016;134:44150.

[3]. Roth G,Nguyen G,Forouzanfar M,Naghavi M, Murray C. Estimates of global and regional premature cardiovascular mortality in 2025. Circulation 2015;132: 1270-82.

[4]. O’Donnell MJ, Chin SL, Rangarajan S, Xavier D, Liu $\mathrm{L}$, Zhang $\mathrm{H}$, et al. Global and regional effects of potentially modifiable risk factors associated with acute stroke in 32 countries : a case-control study. Lancet. 2016; 388(10046):761-75.

[5]. Navya C, Naveen R, Ashwini G et al. "Adherence to medication among diabetic hypertensive patients in selected tea estates in South India," Journal International Medical Sciences Academy.2015; 28(1)16-17.

[6]. Abera $\mathrm{H}$ and Woldemichael M. "Pattern of antihypertensive therapy among diabetic hypertensive patients in Zewditu Memorial Hospital, Addis Ababa," Ethiopian Medical Journal.2016; 54(2):7782.

[7]. Alavudeen S, Alakhali K,Ansari S, and Khan N, "Prescribing pattern of antihypertensive drugs in diabetic patients of Southern Province, Kingdom of Saudi Arabia," Ars Pharmaceutica.2015; 56(2):109114.

[8]. Dhanaraj E, Raval A, Yadav R, Bhansali A, and Tiwari P. "Prescription pattern of antihypertensive agents in T2DM patients visiting tertiary care centre in north India," International Journal of Hypertension .2012, ID 520915 .

[9]. Makoso Nimi B, Longo Longo G, Longo Mbenza B, Makoso Nimi M, Nkongo Mabiala B. Prevalence, awareness, traitment and control of hypertension in Tshela rural areas. DR Congo. IJSRP.2020;10(6) :803-813
[10]. Houehanou C, Amidou S, Preux M, et al. Hypertension artérielle en Afrique subsaharienne. Journal de Médecine Vasculaire 2018 March; 43 (2): 87.

[11]. Ataklte F, Erqou S, Kaptoge S, Taye B, EchouffoTcheugui JB, Kengne AP. Burden of undiagnosed hypertension in sub-Saharan AfricaNovelty and significance: a systematic review and meta-analysis. Hypertension. 2015; 65(2):291-8.

[12]. Makoso Nimi B, Lepira Bompeka F, Longo Mbenza B, Vangu Vangu R Longo Longo G, et al. Prevalence of undiagnosed hypertension among the hypertensive living in the port city of Boma. DR Congo. IJISRT 2020;5(6):197-204.

[13]. Blaise Makoso Nimi, François Lepira Bompeka, Aliocha Nkodila, Williams Ilenga,Gédeon LongoLongo, Dieudonné Vangu Ngoma,et al . Prehypertension, Hypertension and Associated Risk Factors among Adults Living in the Port City of Boma in the Democratic Republic of the Congo. A Population-Based Cross-Sectional Survey". Acta Scientific Cancer Biology 4.5 (2020): 24-32.

[14]. Bayauli MP, M'Buyamba-Kayama JR, Ngoyi NG, Lepira FB, Kayembe KP, Lemogoum D, et al. Trends in prevalence of obesity and hypertension in an urban Congolese community. Journal Epidemiological Research 2018; 4(1): 33-40.

[15]. Katchunga BP, Mbuyamba KJR, Masumbuka EB, Lemogoum D, Kashongwe MZ, Degaute JP et al. Hypertension in adult Congolese population in Southern Kivu: Results of the Vitaraa Study. Presse Médicale 2011. doi: 10.1016/jlpm 2010.10.036.

[16]. Kianu B, Mpembele E, Kintoki EV, Makulo JR, Kiazayawoko FZ, Manyebwa KJDD, et al. Rates of hypertension prevalence, awareness, treatment, and control in Congolese South West Port City.The influence of gender according to groups. Global Journal of Medical Research 2015; 15 (1):1-8.

[17]. Kika T, Kintoki E, M'Buyamba-Kabangu J, Lepira F, Makulo J, Sumaili E, et al. Uncontrolled hypertension among patients managed in primary healthcare facilities in Kinshasa, democratic republic of the Congo. Cardiovasc J Afr. 2016;27(6):361.

[18]. Williams B, Mancia G, Spiering W, et al. Guidelines for the management of arterial hypertension. European Heart Journal 2018; 39 (33):3021-104.

[19]. Report of the Expert Committee on the diagnosis and classification of diabetes mellitus. Diabetes Care 2003; 26(Suppl 1): S5-20.13

[20]. World Health Organization (WHO). The problem of overweight and obesity: preventing and managing the global epidemic. Report Series 894; Geneva, WHO, 2000: 537

[21]. Browning L, Hsieh S, Ashwell M . A Systematic review of waist-to-height ratio as a screening tool for the prediction of cardiovascular disease and diabetes: 0,5 could be a suitable global boundary value. Nutr Res Rev 2010;23:247-69 
[22]. Orth SR, Stockmann A, Conradt C, Ritz E, Ferro M, Kreusser $\mathrm{W}$ and al. Smoking as a risk factor for endstage renal failure in men with primary renal disease. Kidney Int. 2008; 54: 926-31.

[23]. Word Health Organisation TWSatndrfsIW, Available at: http://www.who. int/ncds/surveillance/steps/STEPS_Manual 2017

[24]. Friedewald WT, Levi RI, Fredrickson DS. Estimation of the concentration of LDL-cholesterol without use of the preparative ultracentrifuge. Clin Chem 1972; 18: 499-508.

[25]. Levey AS, Cohen J, Greene T, Stevens LA, Zhang YL, Hendricksen S, et al. Using standardized serum creatinine values in the Modification of Diet in Renal Disease study equation for estimating glomerular filtration rate. Ann Intern Med 2006; 145: 247-254.

[26]. Damasceno A, Azevedo A, Silva-Matos C, Prista A, Diogo D, and Lunet N, 2009. Hypertension,prevalence, awareness, treatment, and control in mozambique: urban/rural gap during epidemiological transition. Hypertension; 54(1): 7783.

[27]. Rayner B, Schoeman HS. A cross-sectional study of blood pressure control in hypertensive patients in general practice (the I-TARGET study). Cardiovasc J Afr 2009; 20(4): 224-227.

[28]. Abiodun OO, Balogun MO, Adebayo RA, Akintomide AO. Blood pressure control and exaggerated blood pressure response in Nigerians with essential hypertension. Clin Med Insights Cardiol. 2014;8:53-56.

[29]. Mutua EM, Gitonga MM, Mbuthia B, Muiruri N, Cheptum JJ, Maingi T. Level of blood pressure control among hypertensive patients on follow-up in a regional referral hospital in Central Kenya. Pan Afr Med J. 2014;18:278.

[30]. Adebolu F and Naidoo M "Blood pressure control amongst patients living with hypertension presenting to an urban district hospital outpatient clinic in Kwazulu-Natal," African Journal of Primary Health Care \& Family Medicine, vol. 6, no. 1, pp. 1-6, 2014.

[31]. Sani MU, Mijinyawa MS, Adamu B, Abdu A, Borodo MM. Blood pressure control among treated hypertensives in a tertiary health institution. Niger $\mathbf{J}$ Med 2008; 17(3): 270-274.

[32]. Omuemu VO, Okojie HO, Omuemu CE. Awareness of high blood pressure status, treatment and control in rural community in Edo State. Niger J Clin Pract 2007; 10(3): 208-212
[33]. Sangsuwan T, Jamulitrat S. Prevalence of uncontrolled blood pressure in hypertensive patients attending the primary care unit of Songklanagarind hospital. Songklanagarind Medical Journal. 2018;36(1):11-27.

[34]. Olowe OA, Ross AJ. Knowledge, adherence and control among patients with hypertension attending a peri-urban primary health care clinic, KwaZulu-Natal. Afri J Prim Health Care Fam Med. 2017;9(1):1-5.

[35]. Jafar TH, Gandhi M, Jehan I, Naheed A, de Silva HA, Shahab H, Alam D, Luke N, Wee Lim C, COBRABPS Study Group. Determinants of uncontrolled hypertension in rural communities in South AsiaBangladesh, Pakistan, and Sri Lanka. American journal of hypertension. 2018;31(11):1205-14.

[36]. Sarfo FS, Mobula LM, Burnham G, Ansong D, Plange-Rhule J, Sarfo-Kantanka O, et al. Factors associated with uncontrolled blood pressure among Ghanaians: evidence from a multicenter hospitalbased study. PLoS One. 2018;13(3):e0193494.

[37]. Ojo OS, Malomo SO, Sogunle PT, Ige AM. An appraisal of blood pressure control and its determinants among patients with primary hypertension seen in a primary care setting in Western Nigeria. S Afr Fam Pract. 2016; 58(6):192-201

[38]. Steyn NP, Mchiza ZJ. Obesity and the nutrition transition in sub- Saharan Africa. Ann NY Acad Sci. 2014;1311:88-101.

[39]. Plante, G.E. Impact of Aging on the Body's Vascular System. Metabolism 2003; 52, 31-35.

[40]. Ramos R, Marrugat J, Basagaña X, Sala J, Masiá R, Elosua R; REGICOR Investigators. The role of age in cardiovascular risk factor clustering in non-diabetic population free of coronary heart disease. Eur J Epidemiol. 2004; 19(4):299-304.

[41]. Virdis A, Giannarelli C, Neves MF, Taddei S, Ghiadoni L. Cigarette smoking and hypertension. Curr Pharm Des. 2010; 16(23):2518-25.

[42]. Reaven GM, Lithell H, Landsberg L. Hypertension and associated metabolic abnormalities--the role of insulin resistance and the sympathoadrenal system. N Engl J Med. 1996 Feb 8; 334(6):374-81.

[43]. Shieva D, Eileen C, Atsuhiko T, Yasuhiko S. Sociodemographic Correlates of Four Indices of Blood Pressureand Hypertension Among Older Persons in Japan. Gerontology. 2013; 59 (5): 1-16.

[44]. M'Buyamba-Kabangu JR, Fagard R, Lijnen P, Staessen J, Ditu MS. Epidemiological study of blood pressure and hypertension in a sample of urban Bantu of Zaïre. Journal of Hypertension. 1986; 4: 485-91. 
ANNEXES

\begin{tabular}{|c|c|c|c|c|}
\hline Variables & $\begin{array}{c}\text { Over All } \\
n=395\end{array}$ & $\begin{array}{c}\text { HUncontrolled } \\
n=245\end{array}$ & $\begin{array}{c}\text { Controlled } \\
n=150\end{array}$ & $\mathbf{P}$ \\
\hline Age, years & $51,3 \pm 12,1$ & $55,9 \pm 9,3$ & $48,4 \pm 12,8$ & 0.007 \\
\hline Age categories, $\mathrm{n}(\%)$ & & & & $<0.001$ \\
\hline$<30$ years & 133(33.7) & $80(32.7)$ & $53(35.3)$ & \\
\hline 30-39 years & $91(23.0)$ & $57(23.3)$ & $34(22.7)$ & \\
\hline $40-49$ years & $53(13.4)$ & $28(11.4)$ & $25(16.7)$ & \\
\hline $50-59$ years & $38(9.6)$ & $15(6.1)$ & $23(15.3)$ & \\
\hline$\geq 60$ years & $80(20.3)$ & $65(26.5)$ & $15(10.0)$ & \\
\hline Gender, n (\%) & & & & 0.505 \\
\hline Male & $230(58.2)$ & $140(57,1)$ & $90(60,0)$ & \\
\hline Female & $165(41.8)$ & $105(42,9)$ & $60(40,0)$ & \\
\hline Residence, $\mathrm{n}(\%)$ & & & & 0.263 \\
\hline Urban & $101(25.6)$ & $62(25.3)$ & $39(26.0)$ & \\
\hline Rural & 294(74.4) & $183(74.7)$ & $111(74.0)$ & \\
\hline Marital status, $\mathrm{n}(\%)$ & & & & $<0.001$ \\
\hline Married & $170(43.0)$ & $95(38.8)$ & $75(50.0)$ & \\
\hline Divorced & $11(2.8)$ & $5(2.0)$ & $6(4.0)$ & \\
\hline Widow & $30(7.6)$ & $9(3.7)$ & $21(14.0)$ & \\
\hline Single & 184(46.6) & $136(55.5)$ & $48(32.0)$ & \\
\hline Education level, n(\%) & & & & $<0.001$ \\
\hline Primary/no & $79(20.0)$ & $40(16.3)$ & $39(26.0)$ & \\
\hline Secondary & $233(59.0)$ & $152(62.0)$ & $81(54.0)$ & \\
\hline University/Superior & $83(21.0)$ & $53(21.7)$ & $30(20.5)$ & \\
\hline $\mathrm{SES}, \mathrm{n}(\%)$ & & & & 0.018 \\
\hline Low & $251(63.5)$ & $160(65.3)$ & $91(60.7)$ & \\
\hline Middle & $111(28.1)$ & $67(27.3)$ & $44(29.3)$ & \\
\hline High & $33(8.3)$ & $18(7.4)$ & $15(10.0)$ & \\
\hline $\mathrm{BMI}, \mathrm{Kg} / \mathrm{m}^{2}$ & $25,1 \pm 4,9$ & $25,8 \pm 3,9$ & $24,7 \pm 5,3$ & 0,311 \\
\hline $\mathrm{WC}, \mathrm{cm}$ & $88,9 \pm 12,3$ & $91,1 \pm 11,4$ & $87,6 \pm 12,8$ & 0.230 \\
\hline $\mathrm{SBP}, \mathrm{mmHg}$ & $125,9 \pm 18,2$ & $141,9 \pm 14,3$ & $116,2 \pm 12,5$ & $<0.001$ \\
\hline $\mathrm{DBP}, \mathrm{mmHg}$ & $81,1 \pm 10,7$ & $89,8 \pm 7,2$ & $75,7 \pm 8,9$ & $<0.001$ \\
\hline $\mathrm{MAP}, \mathrm{mmHg}$ & $96,0 \pm 12,3$ & $107,1 \pm 7,0$ & $89,2 \pm 9,5$ & $<0.001$ \\
\hline Chol T & $174,9 \pm 48,3$ & $180,9 \pm 43,1$ & $171,2 \pm 51,3$ & $<0.389$ \\
\hline LDL & $116,3 \pm 44,4$ & $117,7 \pm 37,4$ & $115,5 \pm 48,5$ & 0.827 \\
\hline $\mathrm{HDL}$ & $38,5 \pm 16,2$ & $42,2 \pm 17,6$ & $36,2 \pm 14,9$ & 0.112 \\
\hline Trig & $100,8 \pm 50,7$ & $105,4 \pm 58,9$ & $97,9 \pm 45,4$ & 0.530 \\
\hline $\begin{array}{c}\text { Prot } 24 \mathrm{~h} \\
\text { Blood Creat } \mathrm{mg} / \mathrm{dl}\end{array}$ & $\begin{array}{c}154,9 \pm 48,8 \\
1,08 \pm 0,34\end{array}$ & $\begin{array}{c}320,6 \pm 75,7 \\
1,15 \pm 0,3\end{array}$ & $\begin{array}{c}53,4 \pm 11,9 \\
1,04 \pm 0,4\end{array}$ & $\begin{array}{l}0.017 \\
0.148\end{array}$ \\
\hline DFGe-MDRD & $94,8 \pm 40,2$ & $102,8 \pm 45,7$ & $81,6 \pm 24,3$ & 0.022 \\
\hline Blood glucose, mg/dl & $184,4 \pm 76,2$ & $185,9 \pm 73,9$ & $183,4 \pm 78,3$ & 0.886 \\
\hline
\end{tabular}

Table 1:- Sociodemographic, biological and clinical characteristics of hypertensive patients

Data are expressed as mean \pm standard deviation, median (interquartile range) absolute (n) and relative (in percent) frequency. Abbreviations: M, male F, female SES, socioeconomic status BMI, body mass index WC, waist circumference SBP, systolic blood pressure DBP, diastolic 
ISSN No:-2456-2165

\begin{tabular}{|c|c|c|c|c|c|}
\hline Variable & $\mathrm{N}$ & All & Male & Female & $\mathrm{P}$ \\
\hline Drug regimen/class & 395 & & 230 & 165 & $<0.001$ \\
\hline 1 drug, $\mathrm{n}(\%)$ & & $245(62.0)$ & $157(68.3)$ & $88(53.3)$ & \\
\hline $\mathrm{CCB}$ & & $170(69.4)$ & $54(54.0)$ & $146(55.9)$ & \\
\hline ACEI & & $53(21.6)$ & $17(17.0)$ & $26(10.0)$ & \\
\hline Loop diuretic & & $7(2.9)$ & $2(2.0)$ & $3(1.1)$ & \\
\hline ARA II & & $6(2.5)$ & $1(1.0)$ & $5(1.9)$ & \\
\hline Betablocker & & $5(2.0)$ & $2(2.0)$ & $3(1.1)$ & \\
\hline Thiazide-like & & $4(1.6)$ & $2(2.0)$ & $2(0.8)$ & \\
\hline 2 drugs, $\mathrm{n}(\%)$ & & $150(38.0)$ & $73(31.7)$ & $77(46.7)$ & \\
\hline $\mathrm{CCB}+\mathrm{ACEI}$ & & $116(77.4)$ & $65(89.0)$ & $51(66.2)$ & \\
\hline CCB +Betablocker & & $20(13.3)$ & $7(9.6)$ & $3(3.9)$ & \\
\hline CCB + Thiazide like & & $14(9.3)$ & $1(1.4)$ & $13(16.9)$ & \\
\hline BP control, $\mathrm{n}(\%)$ & 395 & & 230 & 165 & $<0,001$ \\
\hline No & & $245(62.0)$ & $157(39.7)$ & $88(22.3)$ & \\
\hline Yes & & $150(38.0)$ & $73(18.5)$ & $77(19.5)$ & \\
\hline No BP control types, $\mathrm{n}(\%)$ & 245 & & 157 & 88 & 0.001 \\
\hline Isolated systolic & & $38(15.5)$ & $17(10.8)$ & $21(23.9)$ & \\
\hline Isolated diastolic & & $78(31.8)$ & $62(39.5)$ & $16(18.1)$ & \\
\hline Systolic/diastolic & & $129(52.7)$ & $78(49.7)$ & $51(58.0)$ & \\
\hline
\end{tabular}

Table 2:- treatment and control of hypertension among hypertensive participants

Data are expressed as absolute (n) and relative (in percent) frequencies. Abbreviations: CCB, calcium channel blocker ACEI, angiotensin converting enzyme inhibitor ARA, angiotensin type 1 receptor antagonist BP, blood pressure

\begin{tabular}{|c|c|c|c|c|}
\hline \multirow[t]{2}{*}{ Variables } & \multicolumn{2}{|c|}{ Analyse univariée } & \multicolumn{2}{|c|}{ Analyse multivariée } \\
\hline & $\mathrm{p}$ & OR (IC95\%) & $\mathrm{p}$ & ORa (IC95\%) \\
\hline \multicolumn{5}{|l|}{ Age } \\
\hline$\geq 60$ ans & & 1 & & 1 \\
\hline$<60$ ans & 0,0271 & $3,86(1,62-5,65)$ & 0,005 & $3,43(1,42-4,84)$ \\
\hline \multicolumn{5}{|l|}{ Tabac } \\
\hline Oui & & 1 & & 1 \\
\hline Non & 0,0432 & $4,95(1,37-10,37)$ & 0,047 & $4,91(1,32-11,32)$ \\
\hline \multicolumn{5}{|l|}{ Obésité abdominale } \\
\hline Oui & & 1 & & 1 \\
\hline Non & 0,0280 & $3,66(1,66-6,14)$ & 0,008 & $3,30(1,49-6,49)$ \\
\hline \multicolumn{5}{|l|}{ Stade de MRC } \\
\hline Stade 3,4 ou 5 & & 1 & & 1 \\
\hline Stade 1 ou 2 & 0,032 & $10,20(1,01-10,34)$ & 0,065 & $1,017(0,99-1,04)$ \\
\hline \multicolumn{5}{|l|}{ Hypercholestérolémie } \\
\hline Oui & & 1 & & 1 \\
\hline Non & 0,009 & $2,30(1,85-6,21)$ & 0,014 & $2,20(1,76-6,35)$ \\
\hline
\end{tabular}

Table 3:- Univariable and multivariable analysis of factors associated with controlled BP among hypertensive 